\title{
PENGKUALIFIKASIAN MEREK SEBAGAI BENDA UNTUK DAPAT DIJADIKAN OBJEK JAMINAN
}

\author{
Bekartini Caroline \\ Fakultas Hukum Universitas Katolik Parahyangan \\ E-mail: katiesinaga2608@gmail.com
}

\begin{abstract}
This research were made to explain about how to qualificate a brand into goods in order to make it as a collateral. Furthermore, this research were made to explain about the type of collateral that fit to apply in to a brand. Final result of this research will describe that in spite of a brand didn't classified as a goods as in the intellectual property rights regulation, however basicly when we explored any other regulation, a brand is classified as a goods and so that it could be as a collateral.
\end{abstract}

Keywords: brand; goods; collateral; fiducia.

\begin{abstract}
Abstrak
Kajian ini dibuat untuk menjelaskan bagaimana mengkualifikasikan merek sebagai benda untuk dapat dijadikan objek jaminan. Selanjutnya penelitian ini juga hendak menjelaskan bentuk jaminan seperti apa yang cocok diterapkan pada merek. Hasil akhir dari kajian ini akan menjelaskan bahwa meskipun merek tidak digolongkan sebagai benda di dalam Undang-Undang Merek seperti halnya hak cipta, namun apabila ditelusuri maka pada dasarnya merek termasuk dalam kategori benda dan oleh karenanya dapat dijadikan objek jaminan.
\end{abstract}

Kata Kunci: Merek, Benda, Objek Jaminan, Fidusia. 


\section{A. PENDAHULUAN}

Dunia bisnis saat ini telah berkembang tanpa batas sehingga mampu menerobos berbagai dimensi kehidupan dan perilaku perekonomian. ${ }^{1}$ Perkembangan tersebut tentunya harus diikuti dengan perkembangan hukum positif agar mampu memenuhi kebutuhan para pelaku bisnis dalam hal mendapatkan kepastian hukum untuk menjalankan bisnisnya. Dalam menjalankan bisnis tentunya para pelaku bisnis memerlukan modal yang cukup besar. Modal tersebut biasanya diperoleh melalui pinjaman kredit yang diberikan oleh lembaga keuangan seperti bank. Dalam perjanjian kredit, bank sebagai kreditur akan meminjamkan uang kepada debitur yang disertai dengan agunan sebagai jaminan atas pelunasan utang debitur apabila debitur tidak sanggup membayar utang-utangnya. Agunan tersebut berupa benda baik benda bergerak atau benda tidak bergerak baik yang berwujud maupun tidak berwujud. Di Indonesia bentuk-bentuk agunan kredit yang diakui masih berdasarkan Peraturan Bank Indonesia atau PBI Nomor 14/15/ PBI/2012 tentang Penilaian Kualitas Aset Bank Umum sebagai pengganti PBI Nomor 11/2/PBI/2009 tentang Perubahan Ketiga Atas PBI Nomor 7/2/PBI/2005 tentang Penilaian Kualitas Aktiva Bank Umum dan PBI Nomor 9/6/PBI/2007 tentang Perubahan Kedua atas PBI Nomor 7/2/ PBI/2005 tentang Penilaian Kualitas Aktiva Bank Umum, dalam Pasal 43 meliputi surat berharga dan saham yang aktif di perdagangkan di bursa efek di Indonesia atau memiliki peringkat investasi dan diikat secara gadai, tanah diikat dengan hak tanggungan, mesin yang merupakan satu kesatuan dengan tanah dan diikat dengan hak tanggungan, pesawat udara atau kapal laut dengan ukuran di atas 20 meter kubik yang diikat dengan hipotik, kendaraan bermotor dan persediaan yang diikat dengan fidusia, dan resi gudang yang diikat dengan hak jaminan atas resi gudang. ${ }^{2}$ Dalam perkembangan dunia bisnis saat ini, pengaturan mengenai bentuk agunan kredit tersebut masih sangat terbatas padahal dunia bisnis dan perekonomian melaju sangat cepat. Keterbatasan mengenai bentuk agunan kredit tersebut tentu menyulitkan para pelaku bisnis yang memiliki barang tertentu yang pada dasarnya dapat dijadikan jaminan pelunasan utang namun tidak dapat dijadikan sebagai agunan karena terbentur pada peraturan yang ada, seperti hal nya merek. Merek merupakan bagian dari Hak Kekayaan Intelektual (HAKI). Pengaturan mengenai merek terdapat dalam Undang-Undang No. 15 Tahun 2001 tentang Merek. Oleh karena merek merupakan bagian dari HKI, maka konsep yang terdapat dalam HKI berlaku pada merek. Konsep mengenai HKI dapat dirumuskan sebagai berikut:

1. Pembuat karya dan karya yang dihasilkan harus diakui dan dihargai.

2. Atas hasil karyanya, pembuat karya disamping memiliki hak moral (pengakuan atas dirinya sebagai peng-

1 Rahmat Rosyadi dan Ngatino, Arbitrase Dalam Perspektif Islam Dan Hukum Positif, PT Citra Aditya Bakti, Bandung, 2002, hlm. 1

2 Susilowardani, diakses dari file://C:/Users/DV2/Desktop/Bahan\%20THESIS/Thesis\%20 Susilowardani.pdf, pada tanggal 24 Februari 2016. 
karya) juga memiliki hak ekonomi atas hasil karya tersebut.

3. Pembuatkaryadiberikan perlindungan hukum dalam suatu periode tertentu untuk bisa menikmati hak ekonomi atas hasil karyanya (hak monopoli kreator).

4. Suatu karya yang telah melewati periode waktu tertentu memberikan kesempatan kepada masyarakat umum untuk bisa menikmatinya dengan akses yang lebih terbuka (tidak perlu membayar untuk bisa menikmati hasil karya tersebut).

5. Sejarah hak kekayaan intelektual menunjukkan adanya kecenderungan perlindungan hak monopoli pencipta semakin panjang.

Berdasarkan konsep HKI tersebut, maka dapat kita lihat bahwa HKI memiliki nilai ekonomis, oleh karena itu dapat dikatakan juga bahwa merek yang merupakan bagian dari HKI didalamnya memiliki nilai ekonomis. Melihat pada nilai ekonomis yang ada pada merek, bisa saja di kemudian hari merek dijadikan jaminan dalam perjanjian kredit meskipun belum ada peraturan yang secara khusus mengatur bahwa merek dapat dijadikan obyek jaminan. Apabila dalam praktiknya terjadi bahwa merek dijadikan obyek jaminan meskipun dalam peraturan perundang-undangan yang berlaku belum mengatur atau mengkualifikasikan bahwa merek adalah benda dan oleh karenanya dapat dijadikan obyek jaminan, maka hal tersebut tentu akan menimbulkan kesulitan baik bagi pihak debitur maupun kreditur yang hendak membuat suatu perjanjian utang piutang dengan menggunakan merek sebagai obyek jaminan sebab unsur utama dalam jaminan adalah harus terdapat benda yang dapat dijadikan objek jaminan.

Berdasarkan uraian di atas, maka perumusan masalahnya adalah: Bagaimana mengkualifikasikan merek sebagai benda untuk dapat dijadikan objek jaminan dalam perjanjian kredit serta bentuk jaminan seperti apa yang dapat diterapkan pada merek yang hendak dijadikan objek jaminan.

\section{B. PEMBAHASAN}

Pasal 1 ayat (1) Undang-Undang No. 15 Tahun 2001 tentang Merek memberikan batasan pengertian mengenai merek yaitu tanda yang berupa gambar, nama, katakata, huruf-huruf, angka-angka, susunan warna, atau kombinasi dari unsur-unsur tersebut yang memiliki daya pembeda dan digunakan dalam kegiatan perdagangan. Selain mengacu pada pengertian merek yang terdapat dalam Undang-Undang Merek, para sarjana juga mengemukakan beberapa pengertian tentang merek diantaranya sebagai berikut:

1. H.M.N. Purwo Sutjipto, merek adalah suatu tanda, dengan mana suatu benda tertentu dipribadikan, sehingga dapat dibedakan dengan benda lain yang sejenis. ${ }^{3}$

2. Drs. Iur Soeryatin, suatu merek digunakan untuk membedakan barang yang bersangkutan dari barang sejenis lainnya, oleh karena itu barang yang bersangkutan dengan diberi merek

3 H.M N. Purwo Sutjipto, Pengertian Pokok-Pokok Hukum Dagang Indonesia, Djambatan, 1983, hlm. 82. 
tadi mempunyai tanda asal, nama, jaminan terhadap mutunya. ${ }^{4}$

Merek terdiri dari beberapa jenis. Pasal 1 ayat (2) dan (3) Undang-Undang Merek membagi merek dalam dua jenis yaitu merek dagang dan merek jasa. Khusus untuk merek kolektif sebenarnya tidak dapat dikatakan sebagai jenis merek yang baru oleh karena merek kolektif itu sebenarnya juga terdiri dari merek dagang dan merek jasa. Merek dagang merupakan merek yang digunakan pada barang yang diperdagangkan oleh seseorang atau beberapa orang secara bersama-sama atau badan hukum untuk membedakan dengan barang-barang sejenis lainnya, sedangkan merek jasa diartikan sebagai merek yang digunakan pada jasa yang diperdagangkan oleh seseorang atau beberapa orang secara bersama-sama atau badan hukum untuk membedakan dengan jasa-jasa sejenis lainnya. ${ }^{5}$

Berdasarkan pada reputasi dan kemasyhuran merek dapat dibedakan dalam tiga jenis yaitu merek biasa (normal marks), merek terkenal (well known marks), dan merek termashyur (famous mark). Khusus untuk merek terkenal didefinisikan sebagai merek yang memiliki reputasi tinggi. Merek yang demikian itu memiliki kekuatan pancaran yang memukau dan menarik, sehingga jenis barang apa saja yang berada di bawah merek itu langsung menimbulkan sentuhan keakraban (familiar attachment) dan ikatan mitos (mythical context) kepada segala lapisan konsumen. ${ }^{6}$ Merek merupakan bagian dari Hak Kekayaan Intelektual. Hal ini serupa dengan hak cipta, hak paten, perlindungan varietas tanaman dan tata letak sirkuit terpadu yang kesemuanya itu merupakan bagian dari Hak Kekayaan Intelektual dan merupakan hak kebendaan immaterial yang dapat beralih atau dialihkan. Pasal 3 UU Merek memberikan pengertian mengenai hak merek yang terdapat dalam merek itu sendiri yaitu hak merek merupakan hak eksklusif yang diberikan oleh negara kepada pemilik merek yang terdaftar dalam daftar umum merek untuk jangka waktu tertentu dengan menggunakan sendiri merek tersebut atau memberikan izin kepada pihak lain untuk menggunakannya. Hak eksklusif yang diberikan negara kepada pemilik merek tersebut diberikan dengan maksud untuk mengapresiasi pemilik merek karena telah berhasil menciptakan suatu karya dengan hasil jerih payahnya sendiri dan oleh karenanya pemilik merek tersebut diberikan hak khusus untuk menggunakan merek tersebut secara bebas namun harus tetap sesuai dengan peraturan perundangan yang berlaku serta tidak menganggu orang lain. Di samping itu pemilik merek diberikan juga perlindungan hukum dalam jangka waktu tertentu untuk bisa menikmati hak ekonomi dari hasil karya nya tersebut. Hak merek dapat beralih atau dialihkan. Pengaturan mengenai pengalihan hak merek ini terdapat dalam Pasal 40 UU

4 Suryatin, Hukum Dagang I dan II, Pradnya Paramita, Jakarta, 1980, hlm. 84.

5 H.OK. Sadikin, Aspek Hukum Hak Kekayaan Intelektual (Intelectual Property Rights), PT Raja Grafindo Persada, Jakarta, hlm. 346.

6 Budi Agus Riswandi dan M. Syamsudin, Hak Kekayaan Intelektual dan Budaya Hukum, PT Raja Grafindo Persada, Jakarta, 2005, hlm. 87. 
Merek yang menyatakan bahwa merek dapat beralih atau dialihkan karena beberapa hal yaitu pewarisan, hibah, wasiat, perjanjian atau sebab-sebab lain yang dibenarkan oleh peraturan perundang-undangan. Meskipun merek dapat dialihkan, namun merek tidak dapat dijadikan obyek jaminan sebab UU Merek tidak mengatur hal tersebut secara eksplisit. Berbeda dengan hak cipta yang dapat dijadikan obyek jaminan fidusia dan hal ini dapat dilihat dalam Pasal 16 ayat 3 Undang-Undang No. 28 Tahun 2014 tentang Hak Cipta. ${ }^{7}$ Pasal 16 ayat (1) Undang-Undang Hak Cipta menyatakan bahwa hak cipta merupakan benda bergerak tidak berwujud dan oleh karena nya hak cipta dapat dijadikan obyek jaminan. Namun, didalam undang-undang merek tidak diatur dan tidak disebutkan bahwa merek merupakan suatu benda tidak berwujud dan juga merek dapat dijadikan obyek jaminan.

Seperti yang telah dijelaskan sebelumnya bahwa unsur utama dalam jaminan adalah adanya benda yang dapat dijadikan objek jaminan yaitu benda bergerak dan tidak bergerak baik yang berwujud maupun yang tidak berwujud. Secara umum, benda dibagi menjadi 3 (tiga) kelompok yaitu:

1. Benda berwujud dan benda tidak berwujud;

2. Benda bergerak dan benda tidak bergerak;

3. Benda yang dapat dihabiskan dan benda yang tidak dapat dihabiskan.

Mengenai benda berwujud dan benda tidak berwujud diatur dalam Pasal 503 KUH Perdata yang menyatakan bahwa tiaptiap kebendaan adalah berwujud dan tidak berwujud. "Benda" yang dimaksud dalam KUH Perdata adalah benda berwujud seperti kendaraan bermotor, tanah dan lain-lain. Sedangkan benda tak berwujud seperti hak cipta, paten, tidak diatur oleh KUH Perdata tetapi diatur dengan undang-undang tersendiri. ${ }^{8}$ Definisi benda dapat kita temukan dalam Pasal 499 KUH Perdata yang menyatakan bahwa yang dimaksud dengan benda atau "zaak" adalah segala sesuatu yang dapat menjadi objek hak milik. Yang dapat menjadi obyek hak milik dapat berupa barang dan dapat pula berupa hak, seperti hak cipta, hak paten dan lain-lain. Definisi mengenai hak milik itu sendiri terdapat dalam Pasal 570 KUH Perdata yang menyatakan bahwa Hak milik adalah hak untuk menikmati kegunaan suatu kebendaan dengan leluasa, dan untuk berbuat bebas terhadap kebendaan itu dengan kedaulatan sepenuhnya, asal tidak bersalahan dengan undang-undang atau peraturan umum yang ditetapkan oleh suatu kekuasaan yang berhak menetapkannya, dan tidak mengganggu hak-hak orang lain; kesemuanya itu dengan tak mengurangi kemungkinan akan pencabutan hak itu demi kepentingan umum berdasar atas ketentuan undang-undang dan dengan pembayaran ganti rugi. Perlu diperhatikan bahwa obyek hak milik yang dimaksud dalam Pasal 570 KUH Perdata hanyalah obyek yang memiliki nilai ekonomis. Hal ini secara tegas diatur dalam Pasal 1131

7 Undang-Undang No. 28 Tahun 2014 tentang Hak Cipta.

$8 \quad$ Ibid., hlm. 16. 
KUH Perdata yang menyatakan bahwa segala kebendaan, yang bergerak dan tak bergerakmilik debitur, baikyang sudah ada maupun yang akan ada, menjadi jaminan untuk perikatan-perikatan perorangan debitur itu. Dengan ketentuan yang terdapat dalam Pasal 1131 KUH Perdata tersebut, jelas bahwa hanya kebendaan yang memiliki nilai ekonomis saja yang dapat menjadi jaminan bagi pelaksanaan perikatan, kewajiban, prestasi, atau utang seorang debitur. ${ }^{9}$

Merek merupakan suatu karya yang diciptakan oleh seseorang berdasarkan hasil jerih payahnya sendiri dengan tingkat intelektualitas yang tinggi. Oleh karena itu, negara memberikan apresiasi kepada pemilik merek karena telah mampu menciptakan suatu hasil karya baru dengan cara memberikan hak khusus bagi pemilik merek untuk menggunakan merek tersebut secara bebas namun tetap dalam koridor hukum yang ada dan tidak mengganggu kepentingan orang lain. Disamping itu pemilik merek juga diberikan hak untuk menikmati hak ekonomi dari hasil karyanya tersebut. Adanya hak ekonomi yang diberikan oleh negara kepada pemilik merek, maka dapat disimpulkan bahwa merek memiliki nilai ekonomis. Jika kita melihat pada pengertian benda, maka terdapat 2 unsur utama yang harus dipenuhi agar sesuatu barang dapat dikategorikan sebagai benda sebagaimana yang dimaksud dalam Pasal 499 KUH Perdata yaitu:

1. Merupakan hak milik;

2. Memiliki nilai ekonomis.
Merek merupakan obyek hak milik karena merek melekat secara pribadi terhadap orang yang menciptakan karya tersebut. Disamping itu, merek memiliki nilai ekonomis. Nilai ekonomis yang terdapat pada merek dapat dilihat dari hak pemilik merek untuk melisensikan mereknya kepada orang lain disertai dengan pembayaran royalti. Selain itu, nilai ekonomis yang terdapat pada merek juga dapat dilihat dari tingkat kepuasan konsumen dan manfaat yang diperoleh ketika menggunakan merek tertentu. Hal ini diperkuat dengan Teori Nilai yang dikemukakan oleh Boone \& Kurtz. Menurut Boone \& Kurtz (2007:26) pengertian nilai (value) adalah persepsi konsumen terhadap keseimbangan antara sifat-sifat positif suatu barang atau jasa dengan harganya. Para konsumen yang merasa bahwa mereka telah menerima nilai, yaitu keuntungan positif untuk harga yang wajar, kemungkinan akan tetap puas dan meneruskan relasinya dengan perusahaan. Nilai juga merupakan salah satu cara yang penting untuk membedakan barang dan jasa dari penawaran pesaing. Berdasarkan teori nilai tersebut maka apabila hendak dijadikan objek jaminan, maka nilai ekonomis yang terdapat dalam suatu merek dapat dilihat dari tingkat kepuasaan yang dimiliki oleh konsumen yang menggunakan merek dari suatu barang atau jasa tertentu. Semakin tinggi kepuasan konsumen terhadap merek tersebut maka semakin tinggi pula nilai ekonomis dari merek itu.

9 Djaja S. Meliala, Perkembangan Hukum Perdata Tentang Benda Dan Hukum Perikatan, Nuansa Aulia, Bandung, 2008, hlm. 32. 
Oleh sebab itu, meskipun undangundang merek tidak mengatur bahwa merek merupakan benda sehingga dapat dijadikan objek jaminan, namun apabila kita melihat unsur utama dari benda, maka dapat dikatakan bahwa merek merupakan benda dan oleh sebab itu dapat dijadikan sebagai jaminan.

Selanjutnya ketika merek hendak dijadikan objek jaminan, maka suatu merek harus memenuhi persyaratan suatu jaminan utang yang baik. Secara umum, pengaturan mengenai hukum jaminan terdapat dalam Pasal 1131 KUH Perdata yang menyatakan bahwa segala kebendaan si berutang, baik yang bergerak maupun yang tak bergerak baik yang sudah ada maupun yang akan ada, menjadi jaminan untuk perikatanperikatan perorangan debitur itu. Istilah hukum jaminan merupakan terjemahan dari istilah security of law, zekerheidsstelling, atau zekerheidsrechten. Dalam Keputusan Seminar Hukum Jaminan yang diselenggarakan oleh Badan Pembinaan Hukum Nasional Departemen Kehakiman bekerja sama dengan Fakultas Hukum Universitas Gadjah Mada tanggal 9 sampai dengan 10 Oktober 1978 di Yogyakarta menyimpulkan bahwa istilah "hukum jaminan" itu meliputi pengertian baik jaminan kebendaan maupun perorangan. Berdasarkan kesimpulan tersebut, pengertian hukum jaminan yang diberikan didasarkan kepada pembagian jenis lembaga hak jaminan, artinya tidak memberikan tentang lingkup dari istilah hukum jaminan itu, yaitu meliputi jaminan kebendaan dan jaminan perorangan. Sehubungan dengan pengertian hukum jaminan, tidak banyak literatur yang merumuskan pengertian hukum jaminan. Menurut J.Satrio hukum jaminan itu diartikan peraturan hukum yang mengatur tentang jaminan-jaminan piutang seorang kreditur terhadap seorang debitur. Ringkasnya hukum jaminan adalah hukum yang mengatur tentang jaminan piutang seseorang. Sementara itu, Salim HS memberikan perumusan hukum jaminan adalah keseluruhan dari kaidah-kaidah hukum yang mengatur hubungan antara pemberi dan penerima jaminan dalam kaitannya dengan pembebanan jaminan untuk mendapatkan fasilitas kredit. ${ }^{10}$

Dari dua pendapat perumusan pengertian hukum jaminan diatas dihubungkan dengan kesimpulan Seminar Hukum Jaminan tahun 1978, intinya dari hukum jaminan adalah ketentuan hukum yang mengatur hubungan hukum antara pemberi jaminan (debitur) dan penerima jaminan (kreditur) sebagai akibat pembebanan suatu utang tertentu (kredit) dengan suatu jaminan (benda atau orang tertentu). ${ }^{11}$

Kemudian, suatu jaminan utang yang baik harus memenuhi beberapa persyaratan tertentu yaitu:

1. Mudah dan cepat dalam proses pengikatan jaminan;

2. Jaminan utang tidak menempatkan krediturnya untuk bersengketa;

3. Harga barang jaminan tersebut mudah dinilai;

10 Rachmadi Usman, Hukum Jaminan Keperdataan, Sinar Grafika, Jakarta, 2009, hlm. 1.

11 Ibid. 
4. Nilai jaminan tersebut dapat meningkat, atau setidak-tidaknya stabil;

5. Jaminan utang tidak membebankan kewajiban-kewajiban tertentu bagi kreditur, misalnya kewajiban untuk merawat dan memperbaiki barang, membayar pajak dan sebagainya;

6. Ketika pinjaman macet, maka jaminan utang mudah dieksekusi dengan model pengeksekusian yang mudah, biaya rendah dan tidak memerlukan bantuan debitur. Artinya, suatu jaminan utang harus selalu berada dalam keadaan "mendekati tunai" (near to cash).

Sumber pengaturan mengenai hukum jaminan yang diatur dalam hukum positif Indonesia berdasar dari beberapa peraturan perundang-undangan, diantaranya adalah:

1. Kitab Undang-Undang Hukum Perdata (KUH Perdata).

2. Kitab Undang-Undang Hukum Dagang.

3. Undang-Undang No. 5 Tahun 1960 Tentang Peraturan Dasar Pokok-Pokok Agraria.

4. Undang-Undang No. 4 Tahun 1996 Tentang Hak Tanggungan Atas Tanah Beserta Benda-Benda yang Berkaitan dengan Tanah.

5. Undang-Undang No. 42 Tahun 1999 tentang Jaminan Fidusia.

Selanjutnya, ruang lingkup hukum jaminan terbagi atas dua bagian, yaitu:

1. Jaminan umum, yaitu jaminan yang ditujukan kepada seluruh kreditur dan mengenai segala kebendaan debitur. Setiap kreditur dalam jaminan umum memiliki kedudukan dan hak yang sama terhadap kreditur lain (kreditur konkuren), tidak ada yang diutamakan, diistimewakan dari kreditur lain. Hak jaminan yang bersifat umum ini dilahirkan atau timbul karena undang-undang, sehingga hak jaminan yang bersifat umum tidak perlu diperjanjikan sebelumnya.

2. Jaminan khusus, yaitu kreditor yang piutangnya ditentukan oleh undang-undang sebagai piutang yang diistimewakan dan piutang yang diikat dengan kebendaan tertentu atau dijamin oleh seseorang. Hak jaminan yang bersifat khusus ini timbul karena diperjanjikan secara khusus antara debitur dan kreditor.

Hak jaminan khusus dapat berupa atau dibedakan atas:

1. Hak jaminan yang bersifat kebendaan (zakelijke zekerheidsrechten), yaitu adanya suatu kebendaan tertentu yang dibebani dengan utang. Jaminan kebendaan dibagi menjadi 2 yaitu:

a. Jaminan kebendaan bergerak (gadai dan fidusia);

b. Jaminan kebendaan tidak bergerak (hipotek, hak tanggungan dan fidusia).

2. Hak jaminan yang bersifat perseorangan (persoonlijke zekerheidsrechten), yaitu adanya seseorang tertentu atau badan hukum yang bersedia menjamin pelunasan utang tertentu bila debitur wanprestasi. ${ }^{12}$

Jaminan perseorangan dapat berupa penjaminan utang atau borgtocht 
(personal guarantee), jaminan perusahaan (corporate guarantee), perikatan tanggung menanggung dan garansi bank (bank guarantee).

Hak jaminan kebendaan, sesuai dengan sifat-sifat hak kebendaan, ia memberikan warna tertentu yang khas yaitu:

1. Mempunyai hubungan langsung dengan/atas benda tertentu milik debitur;

2. Dapat dipertahankan maupun ditujukan kepada siapa saja (semua orang);

3. Mempunyai sifat droit de suite, artinya hak tersebut mengikuti bendanya di tangan siapa pun berada;

4. Yang lebih tua mempunyai kedudukan yang lebih tinggi;

5. Dapat dipindahtangankan/dialihkan kepada orang lain. ${ }^{13}$

Jaminan kebendaaan mempunyai ciriciri "kebendaan" dalam arti memberikan hak mendahulu diatas benda-benda tertentu dan mempunyai sifat melekat dan mengikuti benda-benda yang bersangkutan.Adapunjaminanperorangan tidak memberikan hak mendahulu atas benda-benda tertentu, tetapi hanyalah dijamin oleh harta kekayaan seseorang lewat orang yang menjamin pemenuhan perikatan yang bersangkutan. ${ }^{14}$ Atas dasar itu, hak jaminan yang bersifat kebendaan harus kebendaan yang dapat dinilai dengan uang atau benilai ekonomis ketika dijual serta dapat dipindahtangankan atau diasingkan kepada orang lain. ${ }^{15}$ Melihat pada pemaparan mengenai jaminan kebendaan, dapat diketahui bahwa jaminan kebendaan dilakukan atas benda yang memiliki hubungan langsung milik debitur dan dapat dilakukan atas barang bergerak dan tidak bergerak.

Apabila merek hendak dijadikan jaminan maka merek termasuk dalam jaminan yang bersifat kebendaan. Hal ini disebabkan karena merek memiliki sifatsifat yang terdapat dalam hak jaminan kebendaan seperti:

1. Merek merupakan kepunyaan atau hak milik pribadi pemilik merek;

2. Memiliki nilai ekonomis;

3. Dapat dipindahtangankan (sesuai dengan Pasal 40 Undang-Undang Merek);

4. Memiliki sifat droit de suite, mengikuti bendanya ditangan siapapun berada.

Bentuk jaminan utang yang cocok diterapkan pada merek yang hendak dijadikan objek jaminan adalah jaminan fidusia, sebab Jaminan Fidusia merupakan hak jaminan atas benda bergerak baik yang berwujud maupun yang tidak berwujud dan benda tidak bergerak khususnya bangunan yang tidak dapat dibebani dengan Hak Tanggungan yang tetap berada dalam penguasaan pemberi fidusia sebagai agunan bagi pelunasan utang tertentu yang memberika kedudukan yang diutamakan kepada penerima fidusia terhadap kreditor lainnya ( Pasal 1 ayat 2 UU Nomor 42 Tahun 1999 tentang Jaminan Fidusia). Berdasarkan penafsiran dimungkinkan hak kekayaan intelektual (merek) sebagai obyek jaminan fidusia,

\footnotetext{
13 J. Satrio, Hukum Jaminan Hak Jaminan Kebendaan Fidusia, Citra Aditya Bakti, Bandung, 2002, hlm. 1213.

14 Rachmadi Usman, Op.Cit., hlm. 76.

15 J. Satrio, Op.Cit., hlm. 13.
} 
sebagaimana diatur dalam Pasal 1 ayat(2)

UU Jaminan Fidusia yang menyatakan:

"Jaminan Fidusia adalah hak jaminan atas benda bergerak baik yang berwujud maupun yang tidak berwujud dan benda tidak bergerak khususnya bangunan yang tidak dapat dibebani hak tanggungan sebagaimana dimaksud dalam Undang-undang Nomor 4 Tahun 1996 tentang Hak Tanggungan yang tetap berada dalam penguasaan Pemberi Fidusia, sebagai agunan bagi pelunasan utang tertentu, yang memberikan kedudukan yang diutamakan kepada Penerima Fidusia terhadap kreditor lainnya".

Selanjutnya, Pasal 1 ayat (1) UndangUndang Nomor 42 Tahun 1999 tentang Jaminan Fidusia menyatakan bahwa fidusia merupakan pengalihan hak kepemilikan suatu benda atas dasar kepercayaan dengan ketentuan bahwa benda yang hak kepemilikannya dialihkan tersebut tetap dalam penguasaan pemilik benda.

Bentuk jaminan fidusia dikatakan sebagai bentuk yang paling cocok digunakan apabila merek hendak dijadikan objek jaminan sebab pemilik merek tetap dapat menggunakan dan menguasai merek kepunyaannya untuk terus memperoleh penghasilan dengan tujuan agar dapat melunasi utangnya kepada kreditur. Sebab apabila hak kepemilikan merek beralih dari debitur kepada kreditur, lalu bagaimana cara debitur melunasi hutangnya kepada kreditur? Hak kepemilikan baru akan beralih dari debitur kepada kreditur ketika debitur tidak mampu membayar utangnya. Hal ini sesuai dengan Teori Jaminan (lien theory) yang menyatakan bahwa titel kepemilikan dalam suatu sistem jaminan utang tetap berada pada pihak debitur, mencakup juga kekuasaan untuk menguasai dan memungut hasil dari benda objek jaminan utang. Titel kepemilikan dari debitur atas benda objek jaminan utang tersebut baru akan berakhir setelah adanya wanprestasi terhadap utang yang dijamin dan dilakukan eksekusi yang sah sesuai hukum yang berlaku. Jadi, menurut teori jaminan benda ini objek jaminan utang dimaksudkan bukan untuk dinikmati hasilnya, melainkan hanya sebagai jaminan saja untuk berjaga-jaga apabila utang memang tidak terbayar nantinya. Ketika utang memang tidak terbayar, harga pembayarannya akan diambil dari hasil penjualan benda objek jaminan utang. ${ }^{16}$

\section{PENUTUP}

Meskipun undang-undang merek tidak mengatur dan mengkategorikan merek sebagai benda, tetapi apabila kita melihat pada pengertian benda yang terdapat dalam KUH Perdata, maka pada dasarnya merek termasuk dalam kategori benda karena merek merupakan objek hak milik dan memiliki nilai ekonomis. Setiap benda yang merupakan objek hak milik dan memiliki ekonomis, tentunya dapat dijadikan objek jaminan. Oleh karena merek memenuhi kriteria tersebut, maka merek pun dapat dijadikan objek jaminan utang dalam bentuk jaminan fidusia. Bentuk jaminan fidusia paling cocok diterapkan pada merek sebab

16 Munir Fuady, Hukum Jaminan Utang, Erlangga, Jakarta, 2013, hlm. 5. 
pemilik merek dapat terus menggunakan mereknya untuk memperoleh penghasilan dan penghasilan tersebut yang akan digunakan untuk membayar utangnya kepada kreditur.

Pembentuk undang-undang harus melakukan pembaharuan terhadap undang-undang merek dan mengkategorikan merek sebagai benda seperti yang terdapat dalam Undang-Undang Hak Cipta. Hal ini disebabkan karena laju perekonomian di Indonesia sangat cepat. Demi mendukung roda perekonomian dan kegiatan bisnis para pelaku usaha, maka tentu diperlukan ketentuanketentuan hukum yang baru agar para pelaku bisnis dapat terus berinovasi dalam menjalankan bisnisnya dan mudah memperoleh pinjaman dana dari lembaga keuangan seperti bank. Di samping itu, bank sebagai lembaga keuangan yang bertugas menghimpun dan menyalurkan dana dalam bentuk kredit kepada masyarakat juga memperoleh kepastian dan perlindungan hukum apabila ada calon debitur yang hendak melakukan pinjaman kredit dengan objek jaminan berupa merek. dengan kata lain, bank tidak akan ragu untuk memberikan pinjaman dalam bentuk kredit dengan merek sebagai jaminan utang sebab sudah terdapat payung hukum yang melindungi hak-hak kreditur apabila debitur wanprestasi.

\section{DAFTAR PUSTAKA}

\section{Buku:}

Rahmat Rosyadi dan Ngatino, Arbitrase Dalam Perspektif Islam Dan Hukum Positif, PT Citra Aditya Bakti, Bandung.
H.M N. Purwo Sutjipto, Pengertian PokokPokok Hukum Dagang Indonesia, Djambatan.

Suryatin, Hukum Dagang I dan II, Pradnya Paramita, Jakarta.

H. OK. Sadikin, Aspek Hukum Hak Kekayaan Intelektual (Intelectual Property Rights), PT. Raja Grafindo Persada, Jakarta.

Budi Agus Riswandi dan M. Syamsudin, Hak Kekayaan Intelektual dan Budaya Hukum, PT. Raja Grafindo Persada, Jakarta.

Djaja S. Meliala, Perkembangan Hukum Perdata Tentang Benda Dan Hukum Perikatan, Nuansa Aulia, Bandung.

Rachmadi Usman, Hukum Jaminan Keperdataan, Sinar Grafika, Jakarta.

J. Satrio, Hukum Jaminan Hak Jaminan Kebendaan Fidusia, Citra Aditya Bakti, Bandung.

Munir Fuady, Hukum Jaminan Utang, Erlangga, Jakarta.

\section{Peraturan Perundang-Undangan:}

Kitab Undang-Undang Hukum Perdata.

Undang-Undang No. 15 Tahun 2001 tentang Merek.

Undang-Undang No. 28 Tahun 2014 tentang Hak Cipta. 
Undang-Undang No. 42 Tahun 1999 tentang Jaminan Fidusia.

\section{Website:}

Susilowardani, diakses dari file:///C:/ Users / DV 2 / Desktop / Bahan \% 20 THESIS/ Thesis\%20Susilowardani. pdf, pada tanggal 26 Juni 2016. 